\title{
Great cormorant (Phalacrocorax carbo) predation on pikeperch (Sander lucioperca L.) in shallow eutrophic lakes in Poland
}

\author{
Piotr Traczuk, Andrzej Kapusta
}

Received - 08 May 2017/Accepted - 16 June 2017. Published online: 30 June 2017; Inland Fisheries Institute in Olsztyn, Poland Citation: Traczuk P., Kapusta A. 2017 - Great cormorant (Phalacrocorax carbo) predation on pikeperch (Sander lucioperca L.) in shallow eutrophic lakes in Poland - Arch. Pol. Fish. 25: 123-130.

\begin{abstract}
Increases in the population abundance of the piscivorous great cormorant (Phalacrocorax carbo) has led to conflicts with fisheries. Cormorants are blamed for decreased fish catches in many lakes in Poland. The aim of this paper is to describe to role of pikeperch (Sander lucioperca) in the diet of cormorants nesting in a colony on the island in Lake Warnołty. Since the breeding colony is located in the vicinity of Lake Śniardwy, the largest lake in Poland, the cormorants use the resources in this lake. In 2009-2016, 18,432 regurgitated fish were collected, of which 593 were pikeperch. The share of pikeperch among fish collected in 2009-2012 did not exceed $2 \%$, but from 2013 this increased substantially to maximum of $38.2 \%$ in 2015 . The smallest pikeperch had a standard length of $8.4 \mathrm{~cm}$, and the largest $42.5 \mathrm{~cm}$. Pikeperch mean length differed by year, and the length distribution was close to normal. The sizes of the regurgitated pikeperch indicate that cormorants prey almost exclusively on juvenile specimens. The results of the present study indicate that cormorant predation has a significant impact on pikeperch populations in lakes in the vicinity of the colony, and the great cormorants are possibly a significant factor in the effectiveness of pikeperch management. When planning for the management of fish populations in lakes subjected to cormorant predation pressure, it should be borne in mind that
\end{abstract}

P. Traczuk [ $\left.\Xi^{\circ}\right]$

Department of Lake Fisheries, Giżycko

Inland Fisheries Institute in Olsztyn, Poland

e-mail:p.traczuk@infish.com.pl

A. Kapusta

Department of Ichthyology, Hydrobiology, and Aquatic Ecology,

Inland Fisheries Institute in Olsztyn, Poland predation by this piscivorous bird species impacts the abundance and size-age structure of fish populations.

Keywords: lake, Percidae, lake fisheries, fish assemblages

\section{Introduction}

The great cormorant (Phalacrocorax carbo) is a top piscivorous predator that occurs abundantly in the Polish lake district (Krzywosz and Traczuk 2013). Over the past thirty years, the cormorant population has grown dynamically (Przybysz 1997, Bzoma et al. 2013). In 1992, the breeding population amounted of 8,260 nests located in 32 colonies. The trend in the abundance of the great cormorant population has been stable since 2006 and numbers within a range of 25,000-30,000 pairs, of which nearly 6,500 pairs nested in 21 to 24 colonies located in northeastern Poland (Traczuk et al. 2016). The largest lake breeding colony in Poland is located on the island in Lake Warnołty, where there were 295 cormorant nesting pairs in 2005, but this number increased in 2009-2016 and ranged from 1,022 to 1,479 nesting pairs.

The results of numerous studies on cormorant feeding are ambiguous regarding the impact of this species on fish resources and the fisheries (Östman et al. 2013). Differences in assessments of the impact

(c) Copyright by Stanisław Sakowicz Inland Fisheries Institute in Olsztyn.

(c) 2017 Author(s). This is an open access article licensed under the Creative Commons Attribution-NonCommercial-NoDerivs License (http://creativecommons.org/licenses/by-nc-nd/3.0/). 
of cormorants on fish and the fisheries are explained by varied cormorant predation pressure on particular species, fisheries pressure, fish assemblage structure, and even differences in research methods (Salmi et al. 2015). However, the dynamic increase in cormorant abundance is controversial especially among fishers who exploit waters located within the vicinities of breeding colonies or night roosts. Studies of the species composition and quantitative structure of cormorant food have been conducted in northeastern Poland for several decades (Martyniak et al. 1997). An analysis of cormorant food in three breeding colonies in northeastern Poland in 2008-2015 confirmed the occurrence of 26 fish species (Traczuk et al. 2016), which is more than half of the species inhabiting this region. While most cormorant prey were fish of little commercial importance, periodically it included species that are highly prized by local fisheries. One of these species is pikeperch, Sander lucioperca (L.), which are released into the lakes in the region analyzed (Skrzypczak and Mamcarz 2005, Mickiewicz and Wołos 2012). The aim of the present study was to describe the role of pikeperch in the diet of cormorant nesting in a colony located on the island in Lake Warnołty.

\section{Study area}

Lake Warnołty, with a surface area of 338 ha, is a shallow (maximum depth $-6.3 \mathrm{~m}$ mean depth -2.5 $\mathrm{m})$, eutrophic lake located in the northeastern lake district of Poland, which is an elongated, 5-km-long bay of Lake Sniardwy. The cormorant breeding colony is located in the lake on an island with a surface area of 2.9 ha that is fully overgrown with trees, mainly pine and black alder. Precise data on when the colony was established is lacking, but presumably it was in around 2000. When first monitored in 2005, observations indicated that cormorants occupied just a small part of the island and had built 295 nests, and many of the pines they inhabited still had needles. In subsequent years, the number of nesting cormorants grew quickly, and the highest number of nests was noted in 2016 (Fig. 1). Śniardwy, the largest lake in Poland, is located just three to four $\mathrm{km}$ from the cormorant breeding colony and is likely to be its most frequent feeding grounds. Commercial fisheries are conducted in both lakes Warnołty and Śniardwy. Lake Warnołty is a nature reserve, and fishing is conducted for just two weeks in the fall. However, fisheries in Lake Śniardwy have no

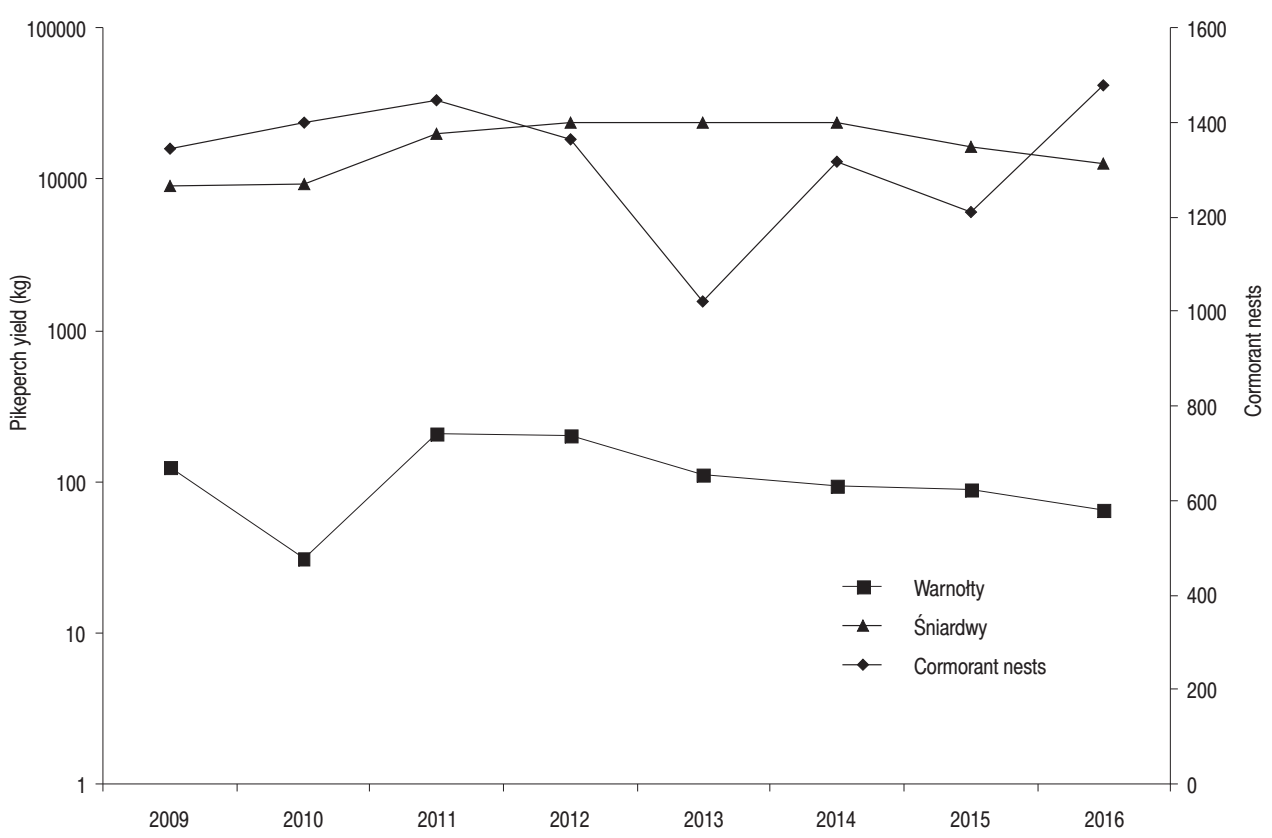

Figure 1. Commercial pikeperch catches in lakes Warnołty and Śniardwy and the number of cormorant nests in the colony located on the island in Lake Warnołty in 2009-2016. 
particular restrictions. The studies on cormorant nesting and feeding were conducted with the permission of the director of the Regional Directorate of Environmental Protection in Olsztyn.

\section{Materials and methods}

The study material comprised regurgitated cormorant prey that was collected from the entire island. Fish that had fallen into the water were not collected. The study was conducted during the breeding season and after it during cormorant night roosting in the colony. Depending on weather conditions, particularly ice cover on the lake, monitoring began in March or April and ended when the birds left the colony during the period from August to October (exceptionally, monitoring ended on May 25, 2015). In the years 2009-2016, the colony was monitored 173 times, but regurgitated fish were not found each time. In total, the colony was monitored 136 times during which all the fish found were collected, for a combined total of 18,432 fish, of which 593 were pikeperch. The fish collected in the field during visits to the colony were identified to the species and measured (standard length (SL) $\pm 1 \mathrm{~mm}$ ). A portion of the fish was considerably damaged from having been in the cormorant digestive tract, which is why the length of partially digested specimens was estimated based on preserved fragments of the fish and sizes of whole specimens. Data analysis also included the structure of commercial catches in lakes Śniardwy and Warnołty in 2009-2016. Data on these catches were obtained from official logs that must be kept by fisheries enterprises exploiting these lakes. Statistical analysis was based on comparing the mean SL of pikeperch collected in different years. First, normal distribution and homogeneity of variance were analyzed, and then many independent samples were tested. The Kruskal-Wallis test and the Dunn test for post-hoc analysis were used
(Statistica 12.0, StatSoft Inc.). The normality of the total length distribution of regurgitated pikeperch in the years analyzed was checked with the Shapiro-Wilk W-test. Dependencies between the quantity of pikeperch regurgitated and the size of commercial catches in lakes Warnołty and Śniardwy were determined with the non-parametric Spearman correlation coefficient.

\section{Results}

The number of nesting great cormorants ranged from 1,022 to 1,479 pairs. Commercial pikeperch catches fluctuated substantially with peaks in Lake Śniardwy in 2012-2014 and in Lake Warnołty in 2011-2013 (Fig. 1). Pikeperch yield in Lake Warnołty was from 0.09 to $0.61 \mathrm{~kg} \mathrm{ha}^{-1}$ and in Lake Śniardwy from 0.83 to $2.17 \mathrm{~kg} \mathrm{ha}^{-1}$. During the period analyzed, pikeperch comprised from 9.9 to $26.6 \%$ of the fish biomass caught by commercial fishers in Lake Śniardwy and $3.9-15.3 \%$ in Lake Warnołty. In 2009-2016, from 645 to 4,753 fish regurgitated by cormorants were collected, including from 10 to 249 pikeperch. Initially, the pikeperch share of the fish collected did not exceed 2\%, but from 2013 this increased substantially to a maximum share of $38.2 \%$ in 2015 (Fig. 2). The dependence between the

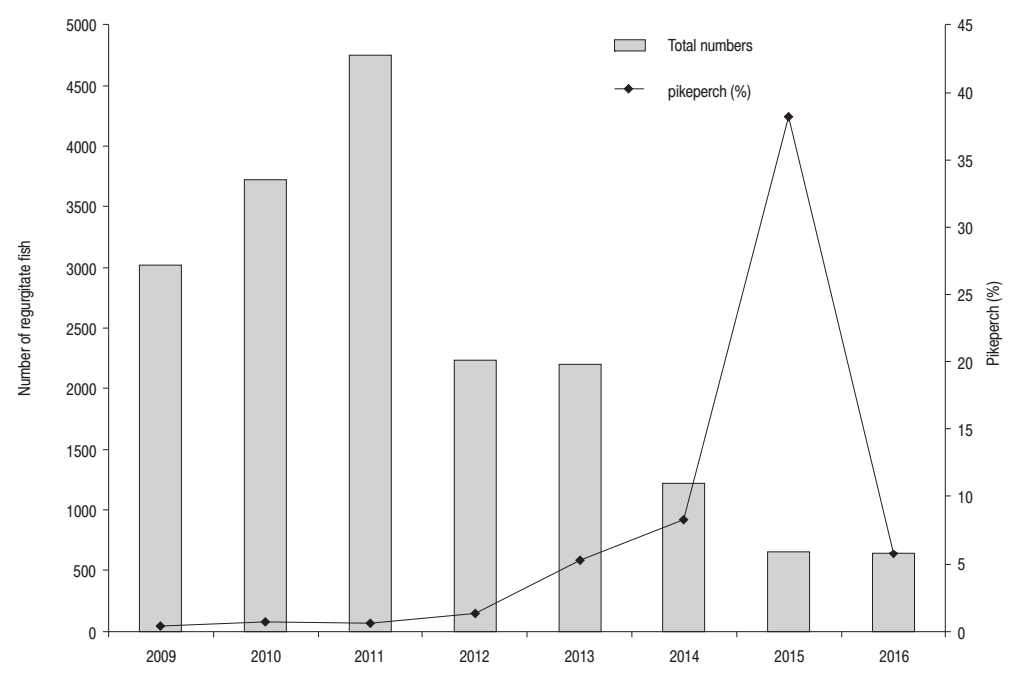

Figure 2. Number of regurgitated specimens and the share of pikeperch in the fish collected at the colony located on the island in Lake Warnołty in 2009-2016. 
Table 1

Dates and number of monitoring trips and characteristics of pikeperch regurgitated by cormorants in the breeding colony on Lake Warnołty in 2009-2016

\begin{tabular}{|c|c|c|c|c|c|c|c|c|}
\hline \multirow[b]{2}{*}{ Year } & \multirow[b]{2}{*}{ Date } & \multirow{2}{*}{$\begin{array}{l}\text { Total } \\
\text { counts }\end{array}$} & \multicolumn{6}{|c|}{ Pikeperch } \\
\hline & & & $\mathrm{N}$ & Mean $(\mathrm{cm})$ & SD & Median (cm) & $\operatorname{Min}(\mathrm{cm})$ & $\operatorname{Max}(\mathrm{cm})$ \\
\hline 2009 & 9 Apr-27 Aug & 22 & 10 & 26.4 & 7.27 & 24.9 & 16.9 & 37.2 \\
\hline 2010 & 22 Apr-13 Oct & 23 & 24 & 24.9 & 4.50 & 24.9 & 17.7 & 32.5 \\
\hline 2011 & 11 Apr-30 Sep & 23 & 28 & 28.7 & 4.78 & 29.2 & 18.6 & 42.5 \\
\hline 2012 & 2 Apr-20 Sep & 25 & 30 & 23.7 & 6.86 & 26.2 & 8.4 & 31.7 \\
\hline 2013 & 23 Apr-7 Oct & 25 & 115 & 21.4 & 4.09 & 20.5 & 11.0 & 35.5 \\
\hline 2014 & 23 Apr-13 Oct & 30 & 100 & 27.4 & 3.34 & 27.4 & 20.6 & 37.8 \\
\hline 2015 & 12 Mar-25 May & 12 & 249 & 28.9 & 3.80 & 29.0 & 18.5 & 40.4 \\
\hline 2016 & 14 Mar-8 Sep & 13 & 37 & 29.4 & 2.89 & 29.8 & 21.5 & 35.2 \\
\hline
\end{tabular}

quantity of regurgitated pikeperch found in the colony and the size of commercial catches of this fish was fairly strong with regard to pikeperch catches in Lake Śniardwy $(r=0.619)$ and weak with regard to those in Lake Warnołty $(r=-0.214)$, but in both instances, it was not statistically significant (Spearman's correlation, $\mathrm{P}>0.05$ ). The mean SL of pikeperch differed significantly in particular years (Kruskal-Wallis test, $\mathrm{P}<0,05$; Table 1). The smallest pikeperch measured $8.4 \mathrm{~cm}$ and the largest measured $42.5 \mathrm{~cm}$. The length distribution of the pikeperch was most frequently close to normal, and rather smoothly shaped in 2009-2012 and sharper in the subsequent period (Fig. 3).

\section{Discussion}

The cormorant is an opportunistic predator, the diet of which is primarily comprised of a few of the most abundant fish species of small sizes (Martyniak et al. 2003, Russel et al. 2003, Gwiazda and Amirowicz 2010, Gaye-Siessegger 2014, Ovegård et al. 2017). Seasonal and spatial variation is often observed in the diet of the cormorant nesting in northeastern Poland (Martyniak et al. 1997, Krzywosz and Traczuk
2012). Roach, Rutilus rutilus (L.), was the dominant dietary component, despite decreases in the share of it in commercial catches that were observed for many years (Krzywosz and Traczuk 2012). Bream, Abramis brama (L.), which dominated commercial catches the Masurian region, was replaced in the cormorant diet by bleak, Alburnus alburnus (L.) and perch, Perca fluviatilis L. Pike, Esox lucius L., also comprised a large share of the cormorant diet in the Masurian region (Traczuk et al. 2016). The food of cormorant nesting in northeastern Poland included mostly fish species that occurred commonly in nearby water basins. Previous studies of the diet of cormorants nesting in this region of Poland indicated that roach dominated in terms of weight followed by bream, tench, Tinca tinca (L.), perch, and pike (Krzywosz and Traczuk 2010a). Cormorants consumed small fish most frequently since the mean body weight of prey was $39.4 \mathrm{~g}$, but some prey weighed nearly $1 \mathrm{~kg}$.

In addition to common species, the cormorant diet also included those that are endangered and protected (Krzywosz and Traczuk 2010b, Delmastro et al. 2015), as well as economically valuable (Wziątek et al. 2010, Troynikov et al. 2013, Salmi et al. 2015). Pikeperch, because of the highly prized of its meat, is in great consumer demand and is fished eagerly by 

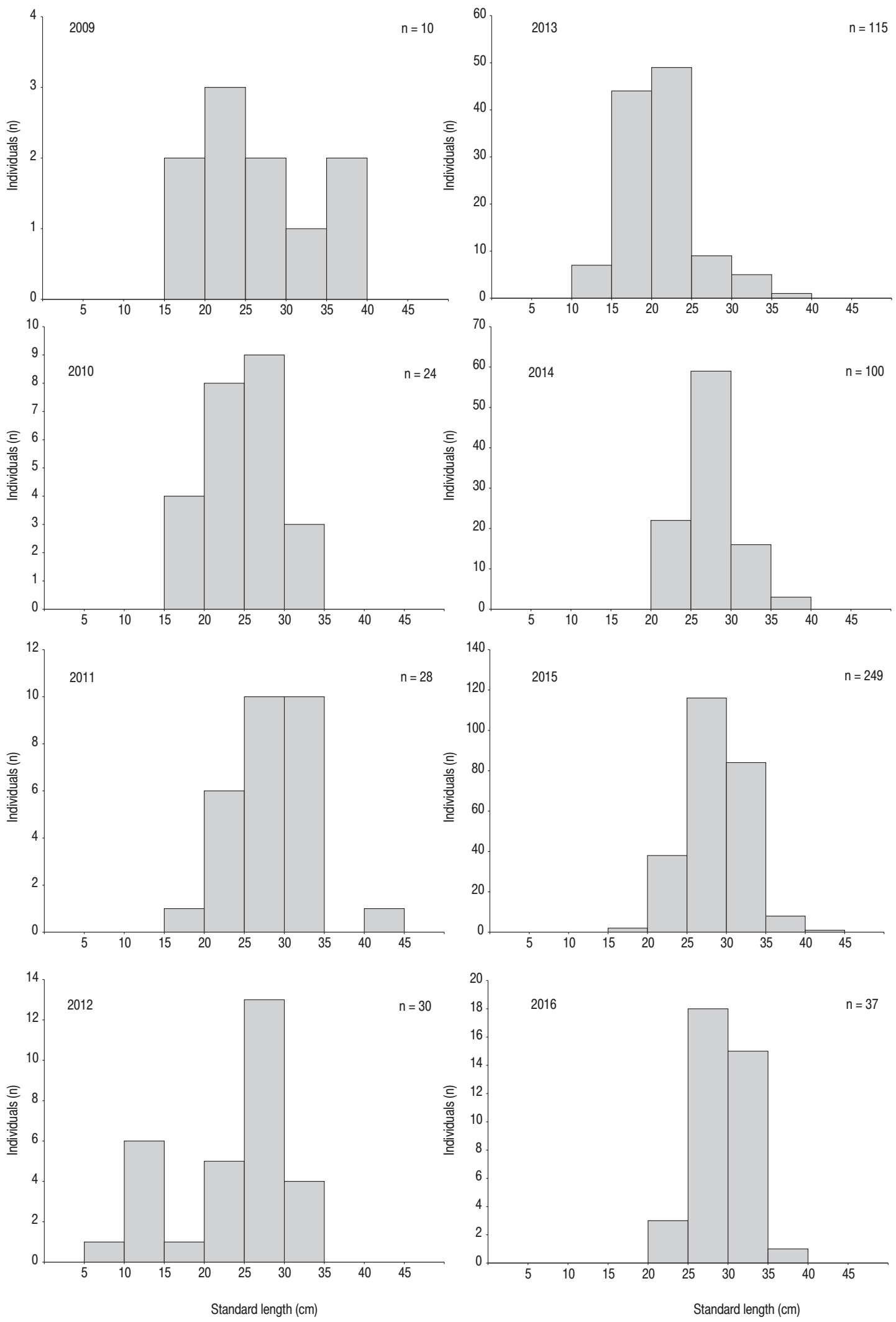

Figure 3. Length frequency distribution of pikeperch caught by cormorants in lakes Warnołty and Śniardwy in 2009-2016. 
commercial fishers in Poland. This species is also very popular among recreational fishers (Bninska and Wolos 2001). Thus, it is not difficult to understand the conflict that arises from cormorants feeding on this species. From 10 to $20 \%$ of all pikeperch in Poland are caught in Lake Śniardwy. Such a large share of pikeperch in the cormorant diet has a significant impact on the management of this species. The body length of regurgitated pikeperch indicated that the prey in the cormorant diet was almost exclusively juveniles that had not yet reproduced. In Polish inland waters, the minimum pikeperch landing size is $45 \mathrm{~cm}$, which is why cormorant feeding on pikeperch could be a significant factor influencing the successful management of this species. The cormorant has been confirmed to impact the abundance and size-age structure of pikeperch populations in the waters of the northern Baltic Sea (Mustamäki et al. 2014).

The results of the present study indicate that cormorant feeding can impact pikeperch populations. These results agree with data in other publications that report pikeperch as being susceptible to cormorant predation (Engström 2001, Mustamäki et al. 2014, Salmi et al. 2015). In many areas where these two species occur together, it has been confirmed that the share of pikeperch in the cormorant diet fluctuates significantly (Emmrich and Düttmann 2011). In the waters of southwest Finland, pikeperch comprises from 0.04 to $10 \%$ of the biomass of the fish consumed (Salmi et al. 2015). In Bavaria, outside of the post-spawning season, it did not exceed $1 \%$ (Keller 1995) or in Holland - 10\% (Dirksen et al. 1995). Krzywosz and Traczuk (2010a), who studied the dietary composition of cormorants in six breeding colonies, conclude that pikeperch comprised approximately $1 \%$ of the total prey biomass throughout the northeast region of Poland. It means that, almost 22 tons of pikeperch was consumed by cormorants annually. Given that official commercial catches of pikeperch in Polish inland waters are about 100 tons (Wołos et al. 2016), it is clear that cormorants consume a large portion of the population of this species.

The northeast of Poland is traditional region in which commercial fisheries are practiced. The lakes of this region are also popular fishing grounds among recreational anglers. Most of the waters are leased from the State, and this requires that lease-holders practice rational fisheries management. In addition to fish catches, lease-holders are obligated to conduct enhancement programs and to adjust catch size to the production capabilities and trophic status of the waters. Fisheries management is planned with at least a ten-year lead time, and the impact of piscivorous animals is one of the factors considered in these plans. The results of this study indicate that when developing plans to manage fish populations in lakes under cormorant predation pressure, how the predation of this piscivorous bird impacts fish assemblage structure must be considered.

This study only used fish that had been regurgitated by the cormorants. The most commonly applied method for determining cormorant dietary composition is to analyze pellets. Comparing the dietary composition determined using the analysis of pellets, regurgitated prey, or cormorants that have been shot leads to dissimilar results (Martyniak et al. 2003, Seefelt and Gillingham 2006). This is why differences associated with cormorant dietary composition, in addition to food availability or seasonal fluctuations, could also be linked with the method applied. In the case of the cormorant colony on the island in Lake Warnołty, supplementary research based on pellet analysis or other methods is required.

Acknowledgments. The authors extend their gratitude to Tadeusz Krzywosz, Professor Emeritus, of the Inland Fisheries Institute in Olsztyn and coordinator of cormorant diet research in 2005-2014 and Professor Łucjan Chybowski, Head of the Department of Lake Fisheries. Additionally, we would like to thank Dr. Dariusz Ulikowski, Dr. Krystyna Kalinowska, Stanisław Sidorski, Wanda Jurgielewicz, Jan Rola, Adam Mańko, Waldemar Kozłowski, and Anna Szostek for assistance in collecting regurgitated fish and laboratory work. The study was partially funded under statutory research topics S-011 (PT), S-024 (PT), S-009 (AK) that are financed by the Inland Fisheries Institute in Olsztyn and partially with European Union funds from the Operational Programme "Sustainable Development of the 
Fisheries Sector and Coastal Fishing Areas 2007-2013"(contract No. 00002-61721-OR400003/ 10/11). Finally we wish to thank Dr. Krystyna Kalinowska who provided valuable comments to improve the manuscript.

Author contributions. P.T. performed the research, P.T. and A.K. designed the research, analyzed the data, wrote the manuscript, and conducted the review of the literature.

\section{References}

Bninska M., Wołos A. 2001 - Management of selected Polish commercial and recreational lake fisheries activities Fish. Manage. Ecol. 8: 333-343.

Bzoma S. Krzywosz T., Betleja J., Orłowska B., Antczak J., Traczuk P., Witkowski J. 2013 - Status of the breeding population of Great Cormorants in Poland in 2012 - In: National reports from the 2012 breeding census of Great Cormorants Phalacrocorax carbo in parts of the Western Palearctic (Eds) T. Bregnballe, J. Lynch, R. Parz-Gollner, L. Marion, S. Volponi, J-Y. Paquet, M.R. van Eerden, IUCN-Wetlands International Cormorant Research Group Report. Technical Report from DCE - Danish Centre for Environment and Energy, Aarhus University. No. 22: 79-81.

Delmastro G.B., Boano G., Conte P.L., Fenoglio S. 2015 Great cormorant predation on Cisalpine pike: a conservation conflict - Eur. J. Wildl. Res. 61: 743-748.

Dirksen S., Boudewijn T.J., Noordhuis R., Marteijn E.C.L.1995 - Cormorants Phalacrocorax carbo sinensis in shallow eutrophic freshwater lakes - prey choice and fish consumption in the non-breeding period and effects of large-scale fish removal - Ardea 83: 167-184.

Emmrich M., Düttmann H. 2011 - Seasonal shifts in diet composition of Great Cormorants Phalacrocorax carbo sinensis foraging at a shallow eutrophic inland lake Ardea 99: 207-216.

Engström H. 2001 - Long term effects of cormorant predation on fish communities and fishery in a freshwater lake Ecography 24: 127-138.

Gagliardi A., Preatoni D.G., Wauters L.A., Martinoli A. 2015 Selective predators or choosy fishermen? Relation between fish harvest, prey availability and great cormorant (Phalacrocorax carbo sinensis) diet - Ital. J. Zool. 82: 544-555.

Gaye-Siessegger J. 2014 - The great Cormorant (Phalacrocorax carbo) at lower lake Constance/Germany: dietary composition and impact on commercial fisheries - Knowl. Manage. Aquat. Ecosyst. 414(04): $1-12$.

Gwiazda R., Amirowicz A. 2010 - Towards the optimal foraging strategy: is seasonal shift in the diet of cormorants Phalacrocorax carbo in a dam reservoir the effect of water temperature or size pattern in fish assemblages? - Pol. J. Ecol. 58: 783-792.

Keller T. 1995 - Food of cormorants Phalacrocorax carbo sinensis wintering in Bavaria, southern Germany - Ardea 83: 185-192.

Krzywosz T., Traczuk P. 2010a - Impact of the great cormorant in lakes in the Masurian region - In: Sustainable exploitation of fishery resources in light of their status in 2009 (Ed.) M. Mickiewicz Wyd. IRS, Olsztyn: 133-142 (in Polish).

Krzywosz T., Traczuk P. 2010b - A local population of vimba bream in Masuria? - Komun. Ryb. 1(114): 22-23 (in Polish).

Krzywosz T., Traczuk P. 2012 - Cormorants and the lakes of Warmia and Masuria - abundance, diet, and impact on fish assemblages and the fisheries - In: Cormorants as a factor in the sustainable exploitation of fisheries resources, Conference materials, Gdynia, November 15, 2012, Morski Instytut Rybacki-PIB: 19-28 (in Polish).

Krzywosz T., Traczuk P. 2013 - Great cormorant, Phalacrocorax carbo, breeding population in Poland in 2013 - Komun. Ryb. 4(135): 25-27 (in Polish).

Martyniak A., Mellin M., Stachowiak P., Wittke A. 1997 Food composition of cormorants Phalacrocorax carbo in two colonies in north-east Poland - Ekol. pol. 45: 245.

Martyniak A., Wziątek B., Szymańska U., Hliwa P., Terlecki J. 2003 - Diet composition of great cormorants Phalacrocorax carbo sinensis at Kąty Rybackie, NE Poland, as assessed by pellets and regurgitated prey Vogelwelt 124 Suppl.: 217-225.

Mickiewicz M., Wołos A. 2012 - Economic ranking of the importance of fish species to lake fisheries stocking management in Poland - Arch. Pol. Fish. 20: 11-18.

Mustamäki N., Bergström U., Ådjers K., Sevastik A., Mattila J. 2014 - Pikeperch (Sander lucioperca (L.)) in decline: high mortality of three populations in the northern Baltic Sea - Ambio 43: 325-336.

Östman Ö., Boström M.K., Bergström U., Andersson J., Lunneryd S.G. 2013 - Estimating competition between wildlife and humans-a case of cormorants and coastal fisheries in the Baltic Sea - PloS One, 8(12): e83763.

Przybysz J. 1997 - The Cormorant - Wyd. Lubelskiego Klubu Przyrodników, Świebodzin, p. 108. (in Polish).

Russel I.C., Cook A.C., Kinsman D.A., Ives M.J., Lower N.J. 2003 - Stomach content analyses of great cormorants Phalacrocorax carbo at some different fishery types in England and Wales - Vogelwelt 124 Suppl.: 255-259.

Salmi J.A., Auvinen H., Raitaniemi J., Kurkilahti M., Lilja J., Maikola R. 2015 - Perch (Perca fluviatilis) and pikeperch 
(Sander lucioperca) in the diet of the great cormorant (Phalacrocorax carbo) and effects on catches in the Archipelago Sea, Southwest coast of Finland - Fish. Res. 164: 26-34.

Seefelt N.E., Gillingham J.C. 2006 - A comparison of three methods to investigate the diet of breeding double-crested cormorants (Phalacrocorax auritus) in the Beaver Archipelago, northern Lake Michigan Hydrobiologia 567: 57-67.

Skrzypczak A., Mamcarz A. 2005 - Pikeperch (Sander lucioperca (L.)) exploitation in reference to stocking programs and the size structure of its habitats in northeastern Poland in 1951-1994 - Arch. Pol. Fish. 13: 193-206.

Traczuk P., Chybowski Ł., Ulikowski D., Kapusta A. 2016 The great cormorant (Phalococorax carbo) in northeastern Poland - A summary of a decade of research - In: Commercial and recreational fisheries in 2015 (Eds) M. Mickiewicz, A. Wołos, Wyd. IRS, Olsztyn: 89-102 (in Polish).
Troynikov V., Whitten A., Gorfine H., Pūtys Ž., Jakubavičiūtė E., Ložys L., Dainys J. 2013 - Cormorant catch concerns for fishers: estimating the size-selectivity of a piscivorous bird - PloS One, 8(11): e77518.

Ovegård M.K., Öhman K., Mikkelsen J.S., Jepsen N. 2017 Cormorant predation overlaps with fish communities and commercial-fishery interest in a Swedish lake - Mar. Freshw. Res. DOI: 10.1071/MF16227.

Wołos A., Draszkiewicz-Mioduszewska H., Mickiewicz M. 2016 - Size and characteristics of lake fisheries production in 2015 - In: Commercial and recreational fisheries in 2015 (Eds) M. Mickiewicz, A. Wołos, Wyd. IRS, Olsztyn: 9-19 (in Polish).

Wziątek B., Martyniak A., Stańczak K., Hliwa P. 2010 - Great cormorant, Phalacrocorax carbo sinensis (L., 1758), pressure on the ichthyofauna of the Włocławek Reservoir and commercial and recreational fisheries management in 2005-2009 - Komun. Ryb. 5: 16-19 (in Polish). 